\title{
Morphological, Anatomical and Palynological Studies on Endemic Matthiola anchoniifolia Hub. -Mor. (Brassicaceae)
}

\author{
Mehmet TEKİN', Gülden YILMAZ2*, Esra MARTINN³ \\ ${ }^{1}$ Cumburiyet University, Faculty of Science, Department of Biology, 58140 Sivas, Turkey; mtekin2280@gmail.com \\ ${ }^{2}$ Trakya University, Faculty of Science, Department of Biology, Balkan Campus, 22030, \\ Edirne, Turkey; guldenyilmaz2009@yahoo.com ("corresponding author) \\ ${ }^{3}$ Necmettin Erbakan University, Faculty of Ahmet Keleşoğlu Education, Department of \\ BiologyEducation, 42090,Konya,Turkey; esramartin@yahoo.com
}

\begin{abstract}
In this paper, anatomical, palynological and seed micromorphological properties of an endemic plant Matthiola anchoniifolia Hub.Mor. are recorded for the first time. A description and descriptive illustrations of the species are given based on the collected specimens for morphological study. Seed surface of $M$. anchoniifolia is examined by scanning electron microscope. The seed of $M$. anchoniifolia was compressed, brownish in colour and the cells of testa were nearly 60-80 $\mu \mathrm{m}$ in diameter and ranged from isodiametric, tetragonal or pentagonal. The anticlinal walls were straight or weakly curved while the outer periclinal walls were concave to flat with smooth surface. In anatomical study, cross sections of root, stem and stem leaf are examined. The root had secondary structure. Periderm consists of 5-8 layers of cells for phellem. Cortex consists of 9-12 layered parenchymatic tissue under the periderm. Secondary phloem ring-shaped, 6-9 layered and consists of companion cells and grouped sieve tubes. Stem had primary structure when analyzed. It is circular with a few irregular ribs in cross section. Cortex is 8-12 layered and parenchymatous. Stoma cells are present on both epidermis. Leaf is isobilateral. There are unicellular and ramified hairs on both surface. Palisade parenchyma cells are 1-2 layered and spongy parenchyma cells are 5-12 layered. M. anchoniifolia has tricolpate pollen type, prolate pollen shape and reticulate exine ornamentation.
\end{abstract}

Keywords: anatomy, endemic, Matthiola anchoniifolia, morphology, palynology, seed, SEM

\section{Introduction}

Brassicaceae has been represented by 365 genus and 3250 species in the world and it is indicated as a huge family (Simpson, 2006). The major centres of distribution of the family are in the Mediterranean, Irano-Turanian and Saharo-Sindian regions (Hedge, 1976). In terms of the Brassicaceae family, Turkey is one of the richest country with 61 genera and 653 native species (Al-Shehbaz et al., 2007). The genus of Matthiola R.Br. (Brassicaceae) is distributing in Africa, Europe and Asia. This genus represented approximately 50 species in the world and with 10 species in Turkey (Cullen, 1965; Dirmenci et al., 2006; Heywood, 1993). Among the endemic taxa identified for Turkey is Matthiola anchonifolia Hub.-Mor., M. longipetala (Vent.) DC. subsp. pumilio (Sibht. \& Smith) P.W. Ball, M. montana Boiss. and M. trojana T. Dirmenci, F. Sat1l \& G. Tümen (Dirmenci et al., 2006; Ekim et al., 2000). M. anchoniifolia has been distributed in Sivas province in Turkey (Cullen, 1965). According to Red Data Book of Turkish Plants, treat category of $M$. anchoniifolia Hub.-Mor. is lower risk/conservation dependent (LR / cd) (Ekim et al., 2000). There is no report on the anatomy, palynology and seed micromorphology of $M$. anchoniifolia which is an en- demic species in Turkey. In this study, morphological, anatomical and palynological properties of $M$. anchoniifolia were given in detail for the first time.

\section{Material and methods}

The specimens which were examined in this study had collected in Sivas (Turkey) from Ulaş and Kangal town in Sivas. The localities were given as follows:

B6 Sivas: Ulaş town, Ziyarettepe, $1406 \mathrm{~m}, 39^{\circ} 33^{\prime}$ $08,9^{\prime}$ N, $37^{\circ} 01^{\prime} 12,1^{\prime \prime}$ E, 12.05.2012, M. Tekin 1189; ibid. 12.06.2012, M. Tekin 1248.

B6 Sivas: Kangal-Gürün road 16. km, 1530 m, 39 07’ 52,2” N, 37 14'33,4” E, 21.06.2012, M. Tekin 1251.

Voucher specimens were deposited in the Cumhuriyet University Herbarium, Faculty of Science and Department of Biology (CUFH). Morphological features and taxonomic descriptions of the plant were carried out according to Cullen (1965). For anatomical studies, the root, stem and stem leaf of the some specimens were fixed and conserved in $70 \%$ ethyl alcohol. Hand sections from fixed material were taken with a razor blade and sections were stained with Alcian blue (Sigma) for pectic substances, Safranin (Sigma) for lignin in the rate of 3/2 (Y1lmaz, 2009). 
164

Sections were waited in blend waited in blend dye about 5 minutes for staining. The stained sections were mounted in glycerin-gelatin to obtain permanent preparations (Jensen, 1962). Sections were examined using an Olympus light microscope BX51. Images were taken with an Olympus DP 70. For palynological investigations the pollens supplied from herbarium specimens and were prepared by Wodehouse method (Wodehouse, 1965). For measurements of polar axis, equatorial diameter, exine thickness and lumina size of pollen grains were used $100 \times$ objective of Olympus light microscope CX21. Measurements were based on 50 pollen grains. For SEM studies, pollen grains coated with gold in a sputter coater. Morphological observations were made and micrographs were taken with a LEO 440 SEM at magnification 5000×; 8500×; 30000×. For morphological descriptions of pollen, followed the terminology of Punt et al. (1994). For seed micromorphology, seeds were mounted on aluminum stubs. Specimen stubs were fixed to the specimen holder of Scanning Electron Microscope (LEO Supra 35 VP FEG SEM) and maintained at accelerating potential voltage of $1.5 \mathrm{kV}$ and photomicrographs

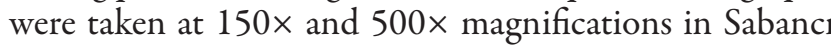
University.

\section{Results and discussion}

Morphological properties [Matthiola anchoniifolia Hub.-Mor. in Bauhinia (1963)] (Fig. 1, 2, 3)

Plant $15-45 \mathrm{~cm}$ and perennial. Stem herbaceous, woody at the base. Basal leaf 15-38 $\times$ 3-7 mm, sessile, linear-oblong to linear-oblanceolat, entire, canescent with dendroid unicellular eglandular hairs. Leaf apex subacute to oblong. Stem leaf 25-56 $\times 3-10 \mathrm{~mm}$, sessile, linear to narrowly oblanceolate, canescent with unicellular branched hairs, entire and subacute at apex. Inflorescence raseme, 4-8 flowered. Flowers hermaphrodite, hypogynous with two planes of symmetry. Bracts absent. Pedicel 2-6 mm at
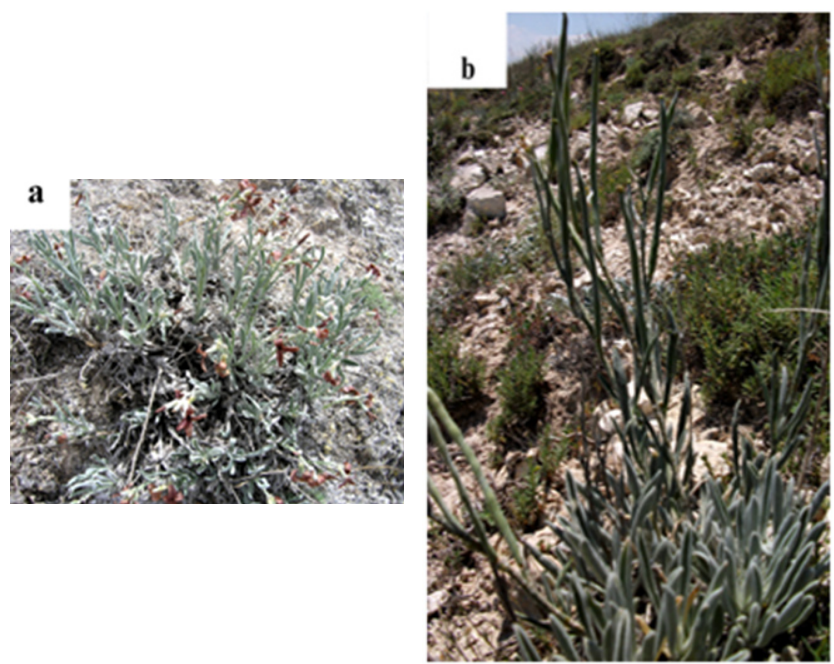

Fig. 1. Matthiola anchoniifolia in natural habitat: a General view in flowering time; b General view in fruiting time anthesis. Calyx 8.8-10.1 mm. Calyx tube length 8-9 mm and diameter $2.5-3 \mathrm{~mm}$. Calyx teeth $0.8-1.1 \mathrm{~mm}$. Corolla cruciform; petals 4, 22-25 $\times 4-6 \mathrm{~mm}$ and brown colored. (Fig. 1, 2); (Tab. 1).

In the present study morphology, anatomy, palynology and seed micromorphology of $M$. anchoniifolia, a narrow deployed endemic species, was examined in detail. Some additions are required for morphological features (Cullen, 1965). Biometric measures belonging to the species is presented in Tab. 1. Cullen (1965) did not report any information about the length of plant, stem leaf, pedicel length at flowering time, inflorescense, calyx, corolla, stamen and pistil features.

In our study the length of plant was about $15-45 \mathrm{~cm}$., stem leaf as $25-56 \times 3-10 \mathrm{~mm}$., inflorescense as raseme and 4-8 flowered. Pedicel length was $2-6 \mathrm{~mm}$ at flowering time. Bract absent, calyx tubular, sepal oblong and $8.8-10.1 \mathrm{~mm}$, calyx tube $8-9 \times 2.5-3 \mathrm{~mm}$; calyx teeth $0.8-1.1 \mathrm{~mm}$. Petal 22-25 × 4-6 mm, approximately oblanceolate and brown colored. Stamen tetradynamous, outer 2 short stamens 6.6-7 mm; inner 4 long stamens 9.2-10 mm. Pistil 3-3.2 $\times 0.7-0.8 \mathrm{~mm}$, lanceolate, canescent and stigma green colored. Although Cullen (1965) reported in Flora of Turkey the basal leaf of $M$. anchoniifolia to be oblong-linear, we determined it to linear-oblong to narrowly linear-oblanceolate and the basal leaf 15-38 $\times$ 3-7 mm in size. Similarly, although Cullen (1965) reported that pedisel length was $7-10 \mathrm{~mm}$ at fruiting time, sliquae $8-12 \times 0.35-0.45 \mathrm{~cm}$ and seed $5 \times 3 \mathrm{~mm}$, we measured pedisel length at fruiting time as $5-12 \mathrm{~mm}$, siliquae $5-15 \times 0.3-0.45 \mathrm{~cm}$ and seed $3-4.2 \times 2-3 \mathrm{~mm}$ in size.

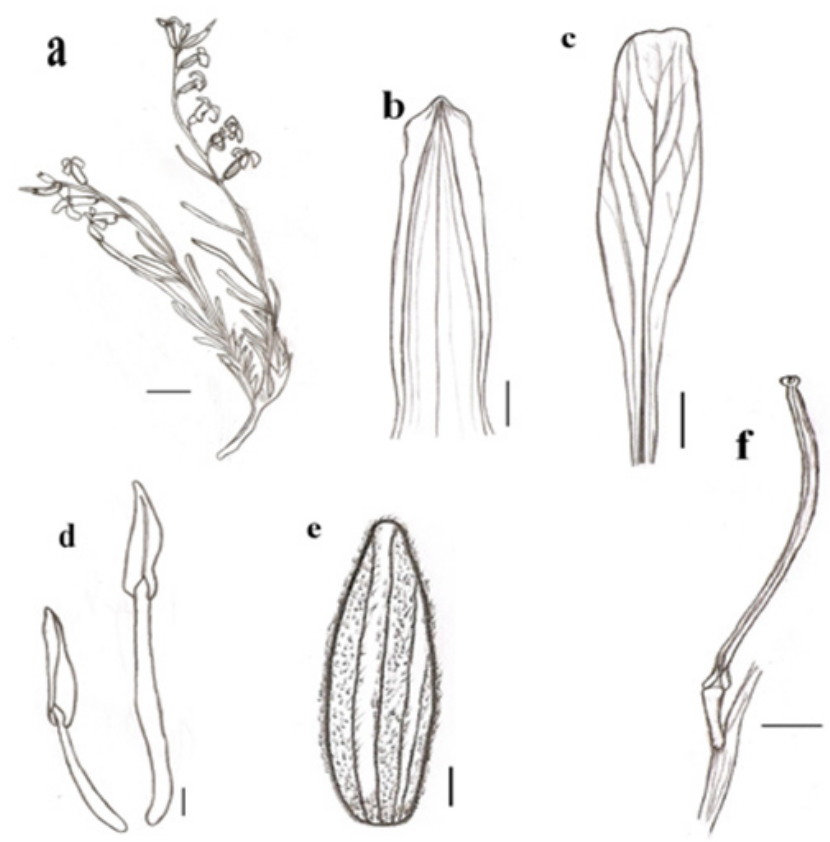

Fig. 2. Drawings of Matthiola anchoniifolia: a General view (Scale bar: $2 \mathrm{~cm}$ ); b Sepal (Scale bar: 1mm); c Petal (Scale bar: $3 \mathrm{~mm}$ ); d Stamens (Scale bar: $0.7 \mathrm{~mm}$ ); e Pistil (Scale bar: 0.4 $\mathrm{mm})$; f Fruit (Scale bar: $1 \mathrm{~cm}$ ) 
Tab. 1. The comparison with literature knowledges of the morphological characters obtained from Matthiola anchoniifolia

\begin{tabular}{|c|c|c|}
\hline & $\begin{array}{l}\text { M. Tekin, G. Yilmaz, E. Martin } \\
\text { (present study) }\end{array}$ & Cullen (1965) \\
\hline Plant length & $15-45 \mathrm{~cm}$ & Not recorded \\
\hline Basal leaf & $\begin{array}{l}15-38 \times 3-7 \mathrm{~mm} \\
\text { sessile, linear oblong to narrowly linear-oblanceolat }\end{array}$ & oblong-linear \\
\hline Stem leaf & $\begin{array}{l}25-56 \times 3-10 \mathrm{~mm} \\
\text { sessile, linear to narrowly oblanceolate, canescent, } \\
\text { entire and subacute at apex. }\end{array}$ & Not recorded \\
\hline Bract & Absent & Not recorded \\
\hline Inflorescence & raseme, 4-8 flowered & Not recorded \\
\hline Pedicel length at anthesis period & $2-6 \mathrm{~mm}$ & Not recorded \\
\hline Pedicel length at fruiting period & $5-12 \mathrm{~mm}$ & $7-10 \mathrm{~mm}$ \\
\hline Sepal & $8.8-10.1 \mathrm{~mm}$ & Not recorded \\
\hline Calyx tube & $8-9 \times 2.5-3 \mathrm{~mm}$, tubular & Not recorded \\
\hline Calyx teeth & $0.8-1.1 \mathrm{~mm}$ & Not recorded \\
\hline Petal & $\begin{array}{l}22-25 \times 4-6 \mathrm{~mm} \text {, brown colored, } \\
\text { approximately oblanceolate }\end{array}$ & Not recorded \\
\hline Stamen & $\begin{array}{l}\text { Tetradynamous } \\
\text { Outer } 2 \text { short stamens } 6.6-7 \mathrm{~mm} \text {; inner } 4 \text { long stamens } 9.2-10 \mathrm{~mm}\end{array}$ & Not recorded \\
\hline Pistil & 3-3.2 $\times$ 0.7-0.8 mm, lanceolate, canescent, stigma green colored & Not recorded \\
\hline Fruit & $\begin{array}{l}\text { Siliquae, } 5-15 \times 0.3-0.45 \mathrm{~cm} \text {, } \\
\text { tomentose and striate }\end{array}$ & $\begin{array}{l}8-12 \times 0.35-0.45 \mathrm{~cm} \text {, } \\
\text { tomentose and striate }\end{array}$ \\
\hline Seed & $\begin{array}{l}3-4.2 \times 2-3 \mathrm{~mm} \text { in size, } 0.3-0.5 \mathrm{~mm} \text { in thickness, oblong } \\
\text { or occasionaly oblong-suborbicular }\end{array}$ & $5 \times 3 \mathrm{~mm}$ \\
\hline
\end{tabular}

The shapes of the cells of testa ranged from isodiametric, tetragonal or pentagonal 60-80 $\mu \mathrm{m}$ in diameter in $M$. anchoniifolia. The anticlinal walls were observed to be straight or slightly curved while the outer periclinal walls were observed to be concave to flat with a smooth surface (secondary sculpture) and a slightly fibrous pattern in $M$. anchoniifolia (Fig. 3).

In previous studies, Tantawy et al. (2004) determined seed morphological characters of $M$. longipetala subsp. $b i$ cornis (Sibth) Ball., M. longipetala (Vent) DC. subsp. hitra (Conti) and M. longipetala subsp. incana R.Br. In M. longipetala subsp. bicornis the seed surface sculpture was reticulate with more or less broad and raised anticlinal walls. The periclinal walls were more or less raised with smooth striated lateral sides and central knobs. However in $M$. longipetala subsp. hitra seeds the seed surface pattern was domate with cracks. The anticlinal walls were shallow raised with smooth irregularly arranged folds running in

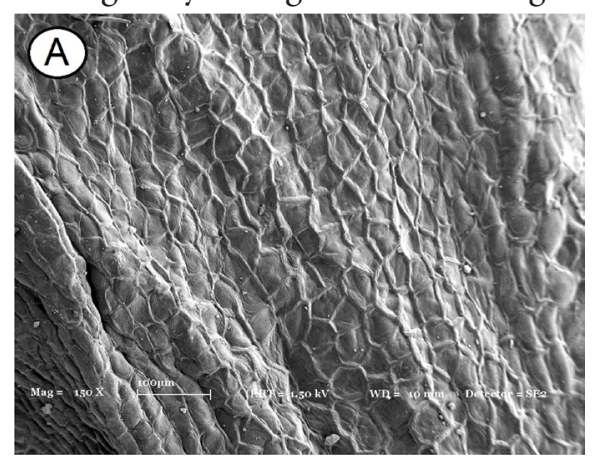

different directions. The periclinal walls were very narrow and deeply depressed. In addition, in the other examined taxa $M$. longipetala subsp. incana the seed surface pattern was reticulate. The anticlinal walls were more or less broad, raised with smooth surfaces. The periclinal walls were shallow depressed with smooth- papillate surface in certain areas and smooth-striated in others (Tantawy et al., 2004). Kasem et al. (2011) investigated seed exomorphic characters of 32 taxa of Brassicaceae by LM and SEM. In their study seed morphological characters of $M$. longipetala (Vent) DC. subsp. incana were determined again and they pointed out that seeds of this taxa were globose and yellowish in colour with glabrous texture. The seed size was $1.5 \times 0.2 \mathrm{~mm}$ (Kasem et al., 2011). In this study seed of $M$. anchoniifolia was compressed, brownish in colour and the cells of testa were nearly $60-80 \mu \mathrm{m}$ in diameter. The anticlinal walls were straight or weakly curved while the outer periclinal walls were concave to flat with smooth surface

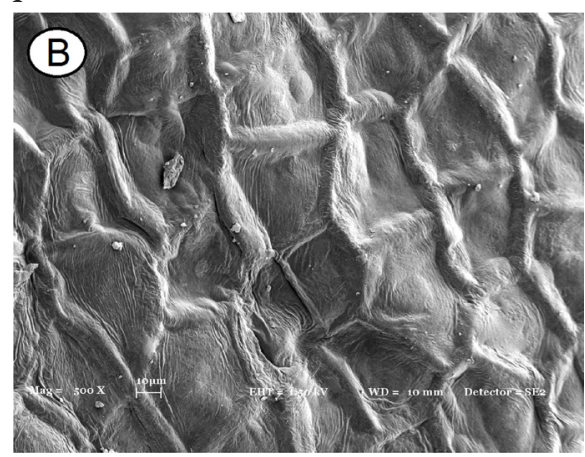

Fig. 3. Seed coat surface of M. anchoniifolia: a General view (Mag. 150x); b Testa surface (Mag. 500x) 
166

in M. anchoniifolia. It was similar to M. longipetala subsp. incana with this feature.

\section{Anatomical properties}

The root had secondary structure when the plants collected. Periderm consists of three different tissues, phellem (5-8 layers of cells are brown due to suberised cell wall), phellogen (1 layer) and phelloderm (1 layer), from exterior to interior. Cortex consists of 9-12 layered parenchymatic tissue under the periderm (Fig. 4).

Parenchyma cells are 40-85 $\times 45-125 \mu \mathrm{m}$ in size. Cambium is not distinguishable. Secondary phloem ringshaped, 6-9 layered and consists of companion cells and grouped sieve tubes. Secondary xylem consist of trachea and tracheid. In the secondary xylem parenchyma cells could be observed between xylem vessels (Fig. 4).

Stem had primary structure when analyzed. Stem is circular with a few irregular ribs in cross section. Epidermis cells are 12-30 $\times 15-40 \mu \mathrm{m}$ in size, ovoid to ovoid-oblong in shape. There are ramified unicellular eglandular hairs on epidermis. Cortex is 8-12 layered and parenchymatous. Cells of cortex are 20-70 $\times 25-100 \mu \mathrm{m}$ in size and ovoidal. There are sclerenchyma fibers between xylem bundles. The pith is large and consists of parenchymatous cells. Pith cells are 35-115 $\times 45-140 \mu \mathrm{m}$ in size and circular to circular-ovoid in shape (Fig. 5).

There is a single layered epidermis on the upper and lower surface of the leaf. Thickness of cuticle is 5-7 $\mu \mathrm{m}$. The shape of epidermal cell is oblong-ovoid. There are unicellular and ramified hairs on both surface. Upper epidermis cells are 18-35 $\times 10-45 \mu \mathrm{m}$ and lower epidermis cells are 15-30 $\times 8-40 \mu \mathrm{m}$. Stoma cells are present on both epidermis. Leaf is isobilateral. Palisade parenchyma cells are 1-2 layered, $12-27 \times 35-70 \mu \mathrm{m}$ and generally cylindrical shaped. Spongy parenchyma cells are 5-12 layered, 10-42 $\times 18-55 \mu \mathrm{m}$ and circular, ovoid or rarely irregular shaped (Fig. 6).

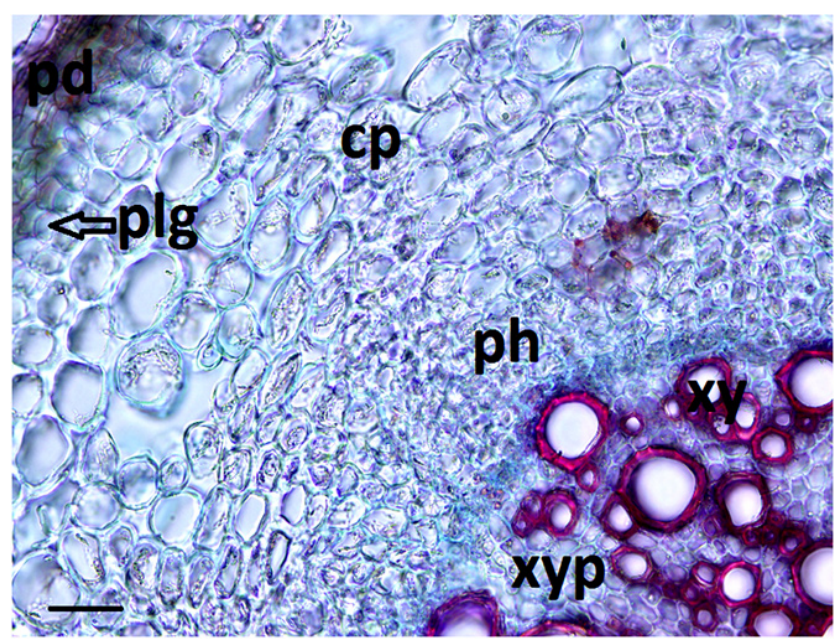

Fig. 4. Cross section of root of Matthiola anchoniifolia: (cp: cortex parenchyma; pd: periderm; ph: phloem; plg: root phellogen; xy- xylem; xyp- xylem parenchyma (Scale bar $=100 \mu \mathrm{m})$

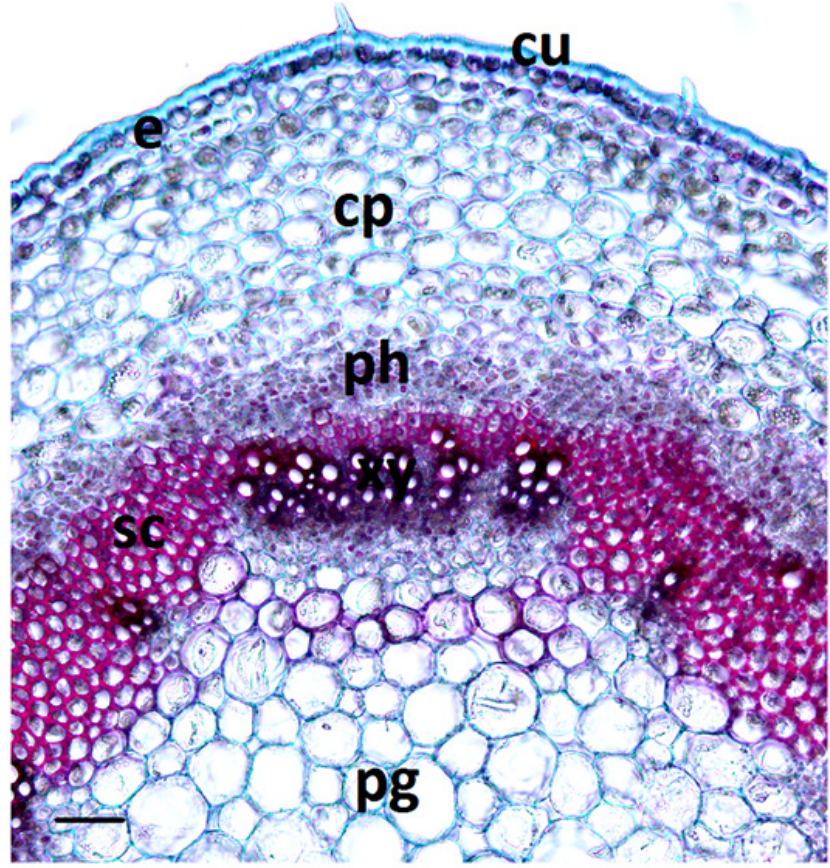

Fig. 5. Cross section of stem of Matthiola anchoniifolia : (cpcortex parenchyma; cu- cuticle; e- epidermis; pg- pith region; sc- sclerenchyma (Scale bar: $100 \mu \mathrm{m})$

\section{Palynological properties}

The shape of pollen grains is prolate. Exine surface ornamentation is coarsely reticulate. Exine thickness is 2.1 $-2.6 \mu \mathrm{m}$ in range and mean $2.4 \mu \mathrm{m}$ (Tab. 2, Fig. 7).

Brassicaceae is a stenopalynous family whose pollen grains are usually tricolpate and reticulate (Erdtman, 1972; Reile, 1992) but there are some differences between members of the same genus as in Hesperis L. in terms of some features, such as pollen shape (Pinar et al., 2009). Properties of pollen morphology of $M$. anchoniifolia were determined with our present palynological measurements and examinations. Our results were compared with those

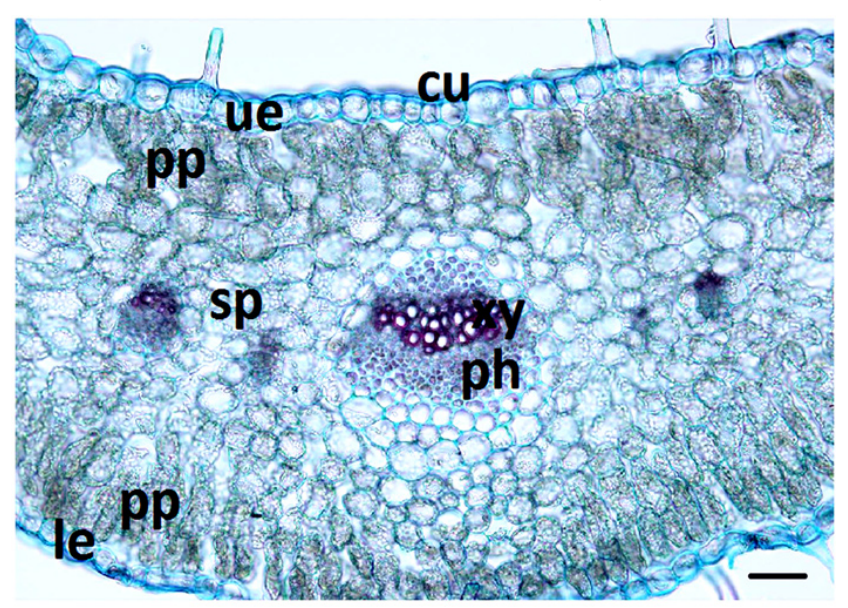

Fig. 6. Cross section of stem leaf of Matthiola anchoniifolia: (cu: cuticle; eh: epidermal hair; le: lower epidermis; ph: phloem; pp: palisade parenchyma; sp: spongy parenchyma; xy: xylem (Scale bar: $60 \mu \mathrm{m})$ 
Tab. 2. The comparison of the pollen morphological characters obtained from Matthiola anchoniifolia with other species (P: polar axis; E: equatorial diameter; P/E: the ratio between the polar axis and equatorial diameter; Pt: Pollen type; Ps: pollen shape; Lumina ca.: lumina size)

\begin{tabular}{|c|c|c|c|c|c|}
\hline Pollen feature & $\begin{array}{l}\text { M. anchoniifolia } \\
\text { Present study }\end{array}$ & $\begin{array}{c}\text { M. arabica } \\
\text { (Abdel Khalik et al.) }\end{array}$ & $\begin{array}{c}\text { M. fruticulosa } \\
\text { (Abdel Khalik et al.) }\end{array}$ & $\begin{array}{c}\text { M. longipetale } \\
\text { subsp. longipetale } \\
\text { (Abdel Khalik et al.) }\end{array}$ & $\begin{array}{c}\text { M. parviflora } \\
\text { (Abdel Khalik et al.) }\end{array}$ \\
\hline Pollen type $(\mathrm{Pt})$ & Tricolpate & Tricolpate & Tricolpate & Tricolpate & Tricolpate \\
\hline Pollen shape (Ps) & Prolate & Prolate & Prolate & Prolate & Subprolate \\
\hline \multicolumn{6}{|c|}{ Polar axis $(\mathrm{P})(\mu \mathrm{m})$} \\
\hline Range & $(20-29)$ & $(25-30)$ & $(27-32)$ & $(28-30)$ & $(24-30)$ \\
\hline Mean & 25 & 29 & 30 & 29 & 28 \\
\hline \multicolumn{6}{|c|}{ Equatorial diameter $(\mathrm{E})(\mu \mathrm{m})$} \\
\hline Range & $(16-20)$ & $(17-20)$ & $(18-21)$ & $(20-22)$ & $(20-30)$ \\
\hline Mean & 18 & 19 & 20 & 21 & 22 \\
\hline $\mathrm{P} /$ E ratio & 1.39 & 1.53 & 1.5 & 1.38 & 1.27 \\
\hline \multicolumn{6}{|c|}{ Lumina ca. $(\mu \mathrm{m})$} \\
\hline Range & $(2.1-4.5)$ & $(2.7-4.5)$ & $(2.5-4.5)$ & $(2.2-2.7)$ & $(3.5-4.5)$ \\
\hline Mean & 3.1 & 3.4 & 3.5 & 2.4 & 3.9 \\
\hline \multicolumn{6}{|c|}{ Exine thickness $(\mu \mathrm{m})$} \\
\hline Range & $(2.1-2.6)$ & Not recorded & Not recorded & Not recorded & Not recorded \\
\hline Mean & 2.4 & Not recorded & Not recorded & Not recorded & Not recorded \\
\hline Ornamentation type & Coarsely reticulate & Coarsely reticulate & Coarsely reticulate & Coarsely reticulate & Coarsely reticulate \\
\hline
\end{tabular}

from related species of the same genus studied by Abdel anchoniffolia is prolate. The palynological study of Abdel Khalik et al. (2002).

Our results confirm the existence of minor differences in pollen size, shape, apertures and exine ornamentation in pollen grains of the other members of Matthiola genus. In Brassicaceae, pollen shapes vary more or less among genera within tribes but very rarely among species within the same genus (Abdel Khalik et al., 2002). The pollen shape of $M$. Khalik et al. (2002) on Matthiola also included M. arabica Boiss, M. fruticulosa (L.) Maire, M. longipetale (Vent.) DC subsp. longipetale. According to this study, all these species had the same shaped prolate pollen grains with the exception of M. parviflora (Schousb.) R. Br. with subprolate grains. When polar axis and equatorial diameter of $M$. anchoniifolia was compared with other Matthiola species,
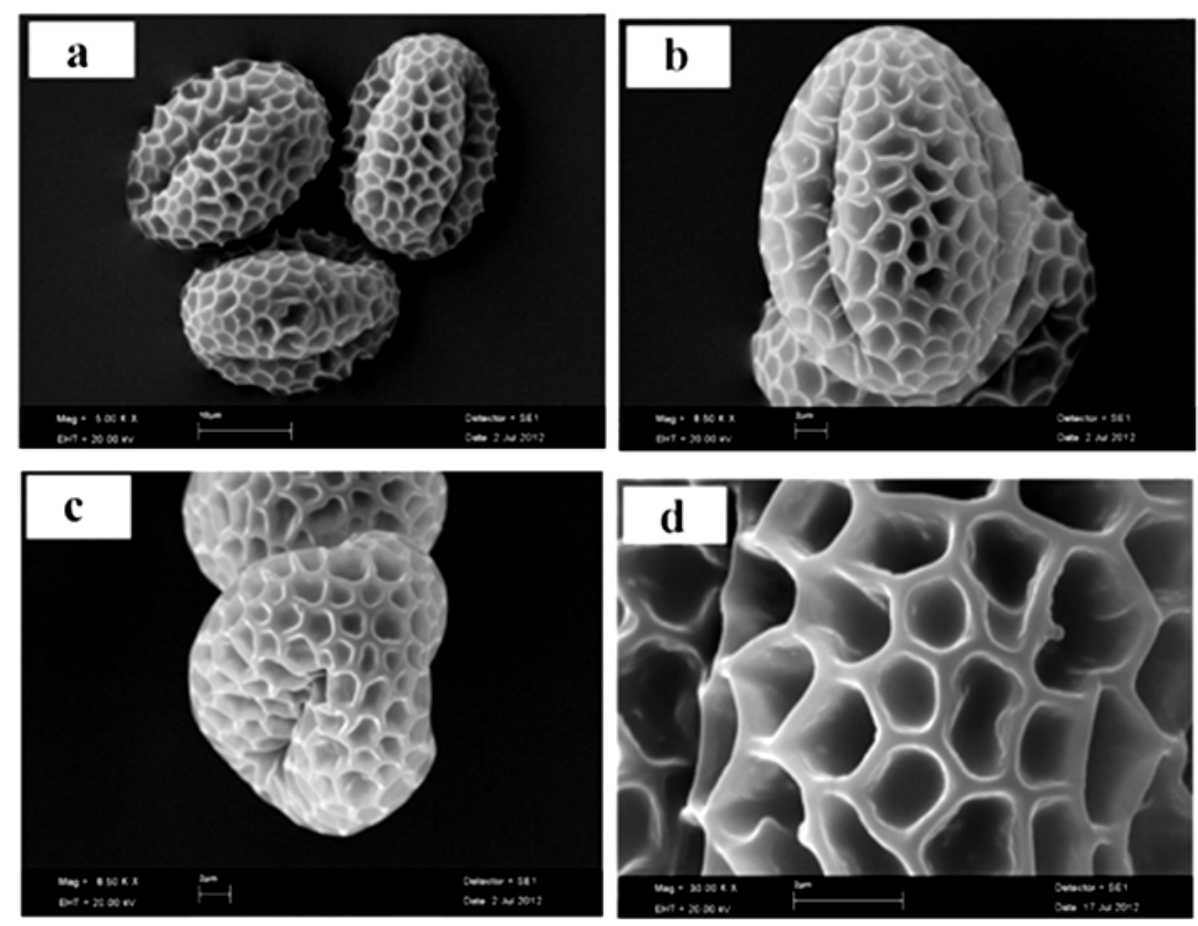

Fig. 7. SEM photographs of pollen of Matthiola anchoniifolia: a Multiple view of pollen (Scale: $10 \mu \mathrm{m})$; b Equatorial view and aperture (Scale: $2 \mu \mathrm{m})$; c Polar view and aperture (Scale: $2 \mu \mathrm{m}$ ) ; d Ornamentation (Scale: $2 \mu \mathrm{m}$ ) 
168

it appeared that pollen grains of $M$. anchoniifolia were the smallest (Tab. 2). Erdtman (1972), Rollins and Banerjee (1979), Lahham and Al-Eisawi (1987) reported slightly colpate or non aperturate pollen grains in a few Matthiola species. Abdel Khalik et al. (2002) reported especially in $M$. arabica that the colpi was less clear. However $M$. fruticulosa, M. longipetale subsp. longipetale, $M$. parviflora and in our study, the colpi of $M$. anchoniifolia was clear. $M$. anchonifolia and all investigated Matthiola taxa in the study of Abdel Khalik et al. (2002) were tricolpate. Exine ornamentation type of $M$. anchoniifolia is coarsely reticulate. Abdel Khalik et al. (2002) reported that exine ornamentation of $M$. arabica, $M$. fruticulosa, $M$. longipetale subsp. longipetale, $M$. parviflora was the same with $M$. anchoniifolia and they were coarsely reticulate. Lumina size of $M$. anchoniifolia, M. arabica, M. fruticulosa, M. parviflora is more or less similar value apart $M$. longipetale subsp. longipetale, which have smaller value of the others. There is no report about exine thickness of Matthiola species in the study of Abdel Khalik et al. (2002) but in this study mean thickness of exine of $M$. anchoniifolia pollen grains was determined as $2.4 \mu \mathrm{m}$ (Tab. 2).

\section{Conclusion}

Morphological, anatomical, palynological and seed micromorphological properties of $M$. anchoniifolia which was an endemic plant in Sivas province were reported in detail for the first time in this study.

\section{Acknowledgements}

We thank to Volkan AKSOY for carefully correcting English of the paper and the staff in Sabancı University for scanning electron microscope.

\section{References}

Abdel Khalik K, Van Den Berg RG, Van Der Maesen JG, El Hadidi MN (2002). Pollen morphology of some tribes of Brassicaceae from Egypt and its systematic implications. Feddes Repert 113:211-223.

Al-Shehbaz IA, Mutlu B, Donmez AA (2007). The Brassicaceae (Cruciferae) of Turkey, Updated. Turk J Bot 31:327-336.

Ardevol-Gonzales JF, Borgen L, Perez De Paz PL (1993). Checklist of chromosome numbers counted in Canarian vascular plants. Sommerfeltia 18:51-59.

Cullen J (1965). Matthiola R. Br., 447-450 p. In: Davis PH (Ed.). Flora of Turkey and East Aegean Islands, vol 1. Edinburgh University Press, Edinburgh, UK.

Dirmenci T, Satil F, Tumen G (2006). A new species of Matthiola R. Br. (Brassicaceae) from Turkey. Bot J Linn Soc 151:431-435.
Ekim T, Koyuncu M, Vural M, Duman H, Aytac Z, Adiguzel N (2000). Red Data Book of Turkish Plants. Turkish Association for the Conservation of Nature, Ankara.

Erdtman G (1972). Pollen morphology and plant taxonomy, New York.

Hedge IC (1976). A systematic and geographical survey of the world Cruciferae, 1-46 p. In: Vaughan JG, Macleod AJ, Jones BMG (Eds.). The biology and chemistry of the Cruciferae, London.

Heywood VH (1993). Flowering plants of the world. Oxford University Press, Newyork, 67-69 p.

Huber-Morath A (1963). Matthiola R. Br., 448 p. In: Davis PH (Ed.). Flora of Turkey and the East Aegean Islands, vol 1. Edinburgh Univ. Press, Edinburgh.

Jensen WA (1962). Botanical histochemistry: principles and practice. WH Freeman and Company, London.

Kasem WT, Ghareeb A, Marwa E (2011). Seed exomorphic characters of 32 taxa of Brassicaceae were investigated by LM and SEM. J Am Sci 7(2):166-178.

Lahham JN, Al-Eisawi D (1987). Pollen morphology of Jordanian Cruciferae Mitt. Bot Staatssamml München 23:355375.

Pinar NM, Duran A, Ceter T, Tug GN (2009). Pollen and seed morphology of the genus Hesperis L. (Brassicaceae) in Turkey. Turk J Bot 33:83-96.

Punt W, Blackmore S, Le Thomas AN (1994). Glossary of pollen and spores terminology. Lab. Paleobot. Palynol., Utrecht.

Reile M (1992). Pollen et spores d'Europe et Afrique du Nord. Lab. Bot. Hist. Palynol., France.

Rollins RC, Banerjee UC (1979). Pollens of the Cruciferae, 3364 p. The Bussey Inst. Harvard Univ.

Simpson MG (2006). Plant systematics. 1 st Edition. ElsevierAcademic Press.

Tantawy ME, Khalifa SF, Hassan SA, Al-Rabiai GT (2004). Seed exomorphic characters of some Brassicaceae (LM and SEM Study). Internat J Agric Biol 6:821-830.

Wodehouse RP (1965). Pollen grains, their structure, identification and significance in science and medicine. Hafner Publish. Company, New York and London, 106-109 p.

Yilmaz G (2009). Determination of toxic effects of herbicide Attribut (propoxycarbazone-sodium) and surfactant BioPower (alkylethersulphate sodiumsalt) on Triticum aestivum L. cv. Pehlivan. PhD Thesis University of Trakya, Institue of Science, Edirne, Turkey. 